\title{
Ruhiology Quotient (RQ) a Bid Concept of National Education Faces the Industrial Revolution Era 4.0
}

\author{
$1^{\text {st }}$ Iskandar $^{1}, 2^{\text {nd }}$ Aletmi $^{2}, 3^{\text {rd }}$ Mufdil Tuhri $^{3}$ \\ \{iskandar@uinjambi.ac.id ${ }^{1}$, aletmialfaqir90@yahoo.co.id ${ }^{2}$, mtuhri@uinjambi.ac.id $^{3}$ \} \\ UIN Sulthan Thaha Saifuddin Jambi ${ }^{1,2,3}$
}

\begin{abstract}
Industrial Revolution Era4.0 confronts people to solve various problems of life by using technology. This situation holds potential that can destroy human dignity through irregularities of using technology. To overcome these problems, so people must have a high level of intelligence to form noble morals. Ruhiology quotient is the highest given by God Almighty for humans which can affect the awareness received by someone who can be known by a human through the pleasure or the feeling emits conscience which is the beginning of the quotient potential possessed by a human. To present Ruhiology Quotient (RQ) for someone who able to detect pagan behavior or misuse of science and technology in the Industrial Revolution Era4.0 that can lead to a multidimensional crisis which is marked by the destruction of human morality, before the potential for deviant behavior can be known through pleasure or feeling through conscience (God Spot) which emanates before it happens, it can be prevented by performing solemn praying that can prevent evil acts. So that, the achievement of the level faith and piety then the person's noble morals can be better.
\end{abstract}

Keywords: Ruhiology Intelligence, National Education System, Industrial Revolution Era 4.0

\section{Introduction}

Mind is a gift that is given by God Almighty. People use their minds to develop science and technology, which aims to achieve life prosperity, even though that does not mean essential happiness [1]. On the contrary, from the experience of human life today it can be seen that there is a tendency for more knowledge and technology to develop, the greater negative impact on the environment is caused by the behavior of human activities related to a multidimensional crisis such as human situations which are often discussed in modern times [2]. The world in general, and Indonesia in particular, is entering a new industry era marked by the digitalization era in various sectors of life, including education. The experts call the Industrial Revolution Era4.0 [3]. The Industrial Revolution Era4.0 (hereinafter: Era 4.0) has an unimportant impact. It affects all aspects of human life. The including is education. This era is marked by the increasingly central role of cyber technology in human life. So it's no wonder that in the education world the term appears "Education 4.0" [4].

The challenge that is faced by educational institutions is how to prepare and map the workforce of education from a graduate who is truly ready for work, in other words, professionals following their fields of expertise, in the face of the Industrial Revolution Era4.0. 
The world of work in the Industrial Revolution Era 4.0 is an integration of internet using with production lines in the industry world that utilize technological and information sophistication. The models and concepts development of education morals are generally developed through the concepts of multiple intelligences. The integration of Islamic values in each subject offering in education can build morals for children very important since early childhood. The importance of understanding dimensions of the education development in the industrial revolution 4.0. HP, the internet is an inseparable part of the daily games that students consume and gives an influence on the behavior changes of students [5].

At present, technological development is being faced by the world including the industrial revolution 4.0 which changes the order of the human life system in the millennial era. The industrial revolution era 4.0 confronts the people to solve various problems of life. The situation holds a potential that can destroy human dignity [6]. To overcome these problems, the person must have a good level of intelligence and morals. A previous study was conducted by [7] stated that the dimensions were most influenced the formation of emotional Quotient and morals were spiritual dimensions. So it can be concluded that Ruhiology Quotient (RQ) is an alternative that can be used to build the level of intelligence and noble morals, it's formed through the education process.

The education refers to Law Number 20 the year 2003 concerning the system of national education article 3, national education aims to develop the student's potential to become human beings who have faith and fear of an almighty god, noble, healthy, have independent creative knowledge, and become a democratic and responsible citizen.

In essence, the purpose of education is to shape the morals of someone faithful and fearful of the God Almighty. The measurement of intelligence level at this time is done by measuring the academic level based on mind and physical mind. The mind is in the form of cognitive women which includes knowledge, understanding, application, synthesis analysis, and analysis. The physical in the form of psychomotor abilities (including imitating manipulating, experiencing, and articulating) and affective (receiving, responding, appreciating, organizing, and moralizing). The measurement of the level of intelligence in Islam is not only based on mental and physical, but based on three main aspects, are namely the five senses, mind and intellect, and intuition.

Intuition is a direct understanding of the truth of religion in reality and the existence of God [8]. The essence of intuition is spirit and strength that play a major role in moral building. The spirit plays an important role in the formation of one's spirituality compared to intellectual intelligence. The modern human is aware of the importance of spirituality. He must return to find his soul because it has been alienated from his forming sources. He is alienated from God Almighty. From creation and tradition, or in other words, alienating from sources that make it aware of its spiritual nature, will require him to return to his constituents. To achieve this, a spiritual approach is needed to foster and direct humanity towards his formation sources. This approach will touch on the inner side of humans which is the core factor of all his actions and thoughts, namely "spirit." So that there needs to study that leads to new theories that lead for Ruhiology Quotient (RQ) which can be used to overcome the multidimensional crisis.

\section{Methodology}

This study uses descriptive qualitative methods that are against the phenomena of facts before, are happening objectively and rationally to describe the concept of Ruhiology Quotient 
(RQ) and the important impact of Ruhiology Quotient (RQ) in national education in the face of the Industrial Revolution Era4.0. The data collection techniques were carried out a library study (Library Research) through a review of the related literature that supported the scientific literature study such as journals, articles, expert interviews on the concept of Ruhiology Quotient (RQ) related to the Qur'an and Hadith.

\section{Result and Discussion}

The progress of science and technology is influenced by the high level of human intelligence over time through the educational process. Intellectual Quotient (IQ), Emotional Quotient (EQ), and Spiritual Quotient (SQ) which are popularized by experts and have been widely adopted and developed by educators in Indonesia which are developed into the core curriculum and local content as well as in the social environment of society have not been able to produce educational outcomes that are by the needs of national education goals. Judging from these behavioral deviations, most of them are conducted by people who have education, who have knowledge and intelligence, but they do deviant behavior, even though someone who shows obedience to worship, its praying is diligent, such as worshiping at a place of worship, then out of the place of worship he conducts behavior that is not commendable [15].

When it is linked to the National Education System Law Number 20 the year 2003 article 3 states that National Education aims to develop the potential of students to be faithful and devoted to God Almighty and noble, healthy, knowledgeable, capable, creative, independent, and to become a democratic and responsible citizen.

The problem is what the process of national education through educational institutions ranging from kindergarten, elementary, secondary to tertiary institutions has maximally developed the most fundamental potential to be developed so that students can be faithful and devoted to God Almighty and have noble morals?

In the implementation of national education trapped in Western theories that always measured intelligence by using the mind and physical intellect in the form of cognitive, affective, psychomotor, but in the aim of national education in the aspect of developing the students potential to be faithful and devoted to God Almighty and possess noble morals had not been maximized so that the progress of science and technology today had a lot of influence on human behavior ranging from lifestyle, way of thinking and social behavior to society that were influenced by sophisticated technological advances in all aspects of life including aspects of education. The multidimensional crisis that occurred in Indonesia in the era of revolution 4.0 which was increasingly widespread deviant behavior shown from all segments of social life through abuse of technology, such as pornography, drugs, online gambling, student brawls, body shaming, corruption, hoaxes, phasing, gadget addicts, plagiarism, online gaming, this indicates that the moral crisis had spread in the community and this could be a threat to the generation of millennia.

Indonesian society is the majority of Islam adherents. So ideally the national education process that is applied to Muslim students must be facilitated by the state to get the right to develop the most basic potential to become a faithful and pious human being and have noble morals derived from and guided by the Qur'an and Hadith, this is in line with the prophet hadith "I leave you two handles, if you hold on to them, you will not be lost forever, namely the holy book of God Almighty (the Qur'an), and the Sunnah of the prophet. Between human and the Qur'an cannot be separated, human is created for al-Quran and the Qur'an is made for human. 
Al-Quran without a human being is useless and humans without the Qur'an have no value. "AlQuran which is the holy book of Muslims revealed to the Prophet Muhammad to be a living guide for humans.

Islam is a religion that carries the thinking intelligence with an objective and honest attitude, and always encourages people to continue for research this universe in earnest, and the Qur'an is a holy book containing information that is the main basis for the power of the human mind to build a smart way of thinking in finding essential facts. It is intended to save the nature of the human creation that has a noble purpose and which is following His affirmation. The inclusion of God Almighty decree, will not only hinder the ability of human thinking but also instead will destroy the values of universal truth which become the morals in the soul of a human being itself, regardless of the religion adopted [9].

The origin of human creation according to the Qur'an [QS Shaad (38): 71-73]

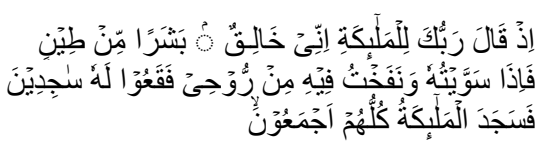

"(Remember) when God says to the angel," Verily I will create a human (Adam) from the ground. If I had completed the incident and infused my spirit, then you should fall on prostrating with it. Then the angel prostrates themselves all". Abba Al Aqad is a contemporary Egyptian scholar and scholar in Al Insan's fil book the Qur'an invites every season, to accept or reject the theory, based on scientific research, without involving the Qur'an in the slightest, because the Qur'an does not speak detail about the validity of the first process. Human intelligence starts from something initial, this is explained in [QS. As-Sajadah (32): 9].

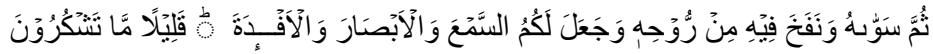

"I perfect the events of human, I am blown by the Spirit, I give Hearing, Vision, and Heart, but very few people are grateful". The word of Spirit that has been blown to humans is the beginning of human intelligence, said the spirit in question is a function of the ear, eye, which are a vision, hearing, even reaching the nervous system that centers on our brain occurs or functions after the soul blows in the human body [10]. God Almighty ordered the prophet to declare that "Spirit is my Lord's affair, whereas you are not given knowledge about it but only a little". [QS. Al-Isra (17): 85).

The spirit (ruh) that God entrusts to human is God's affair and progressive rights that cannot be interpreted by a mind that produces science and technology possessed by human, but human is allowed to have the ability of consciousness and understand how God takes care of the human spirit to survive in the world and goodbye in the afterlife.

Spirit gives a major influence on one's intelligence, and the condition of the spirit greatly influences the process of consciousness that will be received and generated by someone. In addition to the surrounding environment, is the main bias in the sensitivity of spirit, where the intelligence of a person in childhood and adolescence, can be formed and carved with the environment influence. This proves that the soul of a child and teenager that God Almighty blows to them has not been mixed with environmental conditions, which has a major influence on the formation of intelligence [11]. In this life, a human cannot escape from the most central thing in life, namely Spirit, it is the source of life for animate beings. The existence of the Spirit is undoubted, at the same time disputes the Mateshow offlist opinion which states that the 
existence of spirits is not real, they only believe in physical things and appear, without considering the bigger and more powerful things behind this real thing.

Spiritual Quotient is the truest intelligence about wisdom and truth and divine knowledge. This spiritual Quotient results in a very deep love for the truth (mahabbah lillah), so that all of its actions will be guided by the Divine knowledge (the Science of alladunni) which is leads it to ma'rifatullah. Meanwhile, other intelligence is the ability to process all things related to the outer form. Therefore, we can say that every intention that is independent of the values of divine truth is temporal intelligence, while heartiyah spiritual Quotient is authentic, universal, and eternal [ 112$]$.

One indication of Spiritual Quotient is the way a person perceives his life, such as the way a person lives his life, and provides a comprehensive picture that shows the direction in the way human relates to themselves, others, and the surrounding environment based on mahabbah lillah [13]. Ruhiology Quotient (RQ) is closely related to a very basic problem, namely the spirit to make a change of conscience. Ruhiology Quotient (RQ) is the ability of a person to live his life by being combined with divine light that illuminates the heart as a guide for him in taking decisions. A spiritual Quotient is a brilliant ability possessed by a person to relate to God Almighty and fellow human relations, especially in terms of possible impossible deeds [14].

To overcome these problems requires understanding and ability Ruhiology Quotient (RQ). Ruhiology Quotient (RQ) is a potential that is intrinsically blown into the human body, which always invites truth and goodness. This is important to be applied in education which aims to learn the guidance of God Almighty and His Prophet so that the natural tendency in the individual develops correctly and firmly according to the guidance of God Almighty to be a human of faith and piety and noble morals. People who have faith and piety have deep strength that requires encouragement that can move so that they are always given taufik and guidance to be inspired to walk the path of goodness or prevent the path of evil [15]. This is in line with "For the sake soul and perfection (creation), then God Almighty inspires the soul (the way) wickedness and devotion it is the person who cleanses the soul and truly is the one who pollutes it." [Q.S. AlSyams (91): 7-10].

To achieve Ruhiology Quotient (RQ), understanding and awareness are needed to relate vertically between the spirit with the creator of the soul itself, namely God Almighty through this vertical relationship, human beings are required to know themselves and their origin, which has an impact on changes in noble moral behavior.

Two human potentials that must be recognized by every human being are pagan potential and potential believers, as the word of God [Q.S At Taghabun (64) 2].

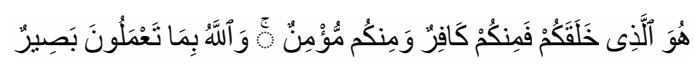

"He who makes you, there are those who are infidels and there are believers." How to recognize the potential of infidels and believers in humans, these two pagan and believing qualities can be known through the conscience of each human being, because humans have a favor that has been granted by God Almighty at the same time the soul blows. This is in line with opinions [13]. The intelligence of a person is the ability to listen to the voice of his conscience or the whisper of truth that is divine in the way he makes decisions and makes choices in behaving.

First: Knowing the substance of pagan nature in humans can be known for the pleasure or taste that is called conscience with the signs: likes to challenge, if you suffer from despair, as described in [Surat Al A'adiyat (100): 6]. 
(Truly human is cruel to his God). Next in [Q.S Al Ma'arij (70) 19-21].

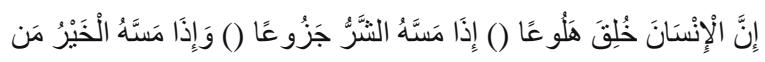

(human is complaining, likes to challenge, if he gets pleasure he is miserly). The continuation of human beings is demonic which can be seen from human behavior that is arrogant, inciting, defamatory, making things that are not known or not known, walking from one human to another they incite and slander. As illustrated in [Q.S Ashy Syu'ara (26) 221-226]

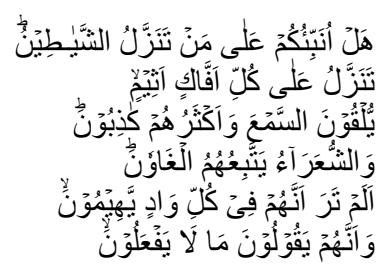

"Will I tell you who the descent is. The devil descends to every liar, a liar who has many sins, they confront hearing and most of them are liars. And the poets are followed by misguided people, do not you see that they are actually walking from the valley of humility, and indeed they say what they do not do ".

Second: Knowing the substance of the believer whose name is Spirit, as for the nature of spirit, namely (1) sidiq means true, who comes rather than God Almighty is named believer, as for the signs: Never lie, when lying, lying, awkward, show off, jealous envy, slander, greedy, stingy and arrogant, all human can know to hear it and feel through wisdom or taste known as conscience; (2) Amanah means God's trust. God does not ask the mouth, but God accepts trust. (God does not see your appearance and your charity, only looks at your heart and your intentions (which intends to be in the heart that is seen by God); (3) Tabligh means to convey. If not he (believer/spirit) who conveys to God Almighty, will not be accepted by God Almighty, of course, must know where the nature is, and (4) Fatanah means Intelligent and wise. He is very careful, does not want to hurt the feelings of others, everything he does, he thinks first, what are the benefit and what harm, therefore do not quickly say to be true or false, but weigh the good and bad benefits of harm, as you may hate something even though it is good for you, you may like something, even though he is bad for you God Almighty knows, while you do not know. [QS Al Baqarah (2 ) 216].

How does God separate the resolve between the differences between pagan and believer substances that exist in humans? So the believers are obliged to pray, "Verily, for those who believe, those who are special in their prayers, and those who abstain from (useless actions and words) and those who pay alms, and the people who guard their genitals. [Q.S Al-Mu'minun (23) 1-5].

On the contrary, the blessing must be fulfilled, namely following the Apostle. "And established prayer, gave charity, and joined the apostle, so you are given mercy. [Q.S. An-Nur (24): 56)."

The address is in the Baitullah. "And (remember), when we made that house (Baitullah) a gathering place for human and a safe place. And it is made as part of the tomb of ibarahim and islmail places, cleanse my house for those who thawaf are I'tikaf, bow and prostrate. "[Q.S Al Baqarah (2) 125].

What is the purpose of praying, so that human disbelief substance is cruel, complaining, and challenging before it happens can be prevented. "Read what has been revealed to you, namely 
the holy book (Al-Quran), and establish prayers. Surely the praying prevents evil. And remembering God Almighty (praying) is greater (its superiority than other services). And God Almighty knows what you do. [Q.S Al Ankabut (29) 45].

In line with Ahmad Juntika Nursihan's opinion that human is a very creative creature, full of imagination. If his potential is separated from the divine light, then the entry of his heart is demonic power so that all his creativity, his imagination, can mislead the views of other human births. This is where the importance of the role of the heart is always tapped from within so that moral awareness arises and a sense of responsibility as human beings in togetherness with other humans. The beat is nothing but a spiritual potential that always invites people to universal Divine truths, such as godly invitations, peace, love, and friendship. Godly potential as human nature residing in spirit, never lost, and one day he appeared to awaken humans. This is where the importance of education is trying to develop spiritual Quotient by cleansing and enlightening heart. Because the clean and bright heart always listens to the spiritual whisper that is sharp and sensitive to external stimuli. Heart who are dominated by spiritual light who always divinely (in metaphor called soar) seek, long for, and realize the value of truth will be more sensitive and provide a very deep "former" element so that within us there will be a kind of sensory intra sensory perception to six who said yes or no in making a decision. That is why God Almighty calls heart to account for all his attitudes and behavior because all human actions are decided by heart

The substance of prayer is the believer, the believer is the servant of filqalbi mu'minini (my servant who is in their hearts is namely the believer), that is the name of spirit who comes from Muhammad (Ana minallah walmu'minuuna minniiy). I am from God and a believer than me. So the praying as a tool is spiritually related to God, through Ruhiology Quotient (RQ) can be awakened when we always sharpen it / train it to feel the inner voice to carry out the truths are commanded by God Almighty, turn on the vibrations of the soul through intrinsic awareness. This awareness is required from a solemn praying process. As for the solemn praying is [Surah Al Mu'minum (23) 1-5]: Which Means: "Surely wins the believers in solemn praying and stirs to God Almighty. And the people who turn away from futile deeds and people pay alms and people who maintain their honor. "That's why before there is a cruel act that can be prevented because surely every human being must know and listen to the nature of arousal ('ain-real). It the importance for Muslims to be able to perform praying solemnly, namely when the heart and mind are fully focused only on God Almighty, are not disturbed by other things that often arise, including the devil.

Liken the image of a human being in the mirror as a devil who can do various forms of evil [16]. Even though to be able to pray solemnly, the heart and mind or spirit of a human is directed to the Qiblat or Baitullah. "Imagine that we are facing and as if we were in the house (Baitullah) so that we can communicate with God Almighty, then that is where our praying is solemn. If the believer can achieve that, then there is nothing to worry about [17].

Five centuries after being left by Prophet Isa, humans were in savagery. The strong are powerful, the poor people were trampled, women had not to price, all could be used, it was known as the dark era; then the great Prophet Muhammad was born who returned to the lost nature by example directly; presided over the Umrah and Hajj ceremonies which began with taking Miqot in Zulhulaifah, Bir Ali in Medina on the 8th of Zulhijjah. It was on this occasion that he directed that Muslims educate prayer in the House. As [Q.S Al baqarah (2) 125]: "And remember when we made that house baitullah a temple to go back and forth to people and safe places. And take the House baitullah of Praying place. Clean up my house for those who pay tawaf, I 'tikaf, rukuk, and Sujud. 
Furthermore, we were left behind by the Prophet Muhammad SAW for fifteen centuries, the development of believers in practicing religion were increasingly developing through writings in the form of views, appeals, and has talked about human morals, but unfortunately, it did not touch the substance of the cause or substance of the solution or the way out. He had also carried out Islamic studies through the Text, a limited context with limited brain abilities that have caused ceaseless disputes. So the Muslim community had been divided into groups, class groups, religious groups.

As explained in [QS Ar Ruum (30) 31-32]:

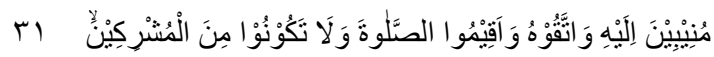

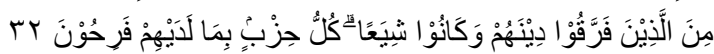

Meaning: "in return to Him and obey Him and establish praying, and do not be among the polytheistic, those who divided their religion and become them some class, each group was proud of what they had.".

Unfortunately, to this day, we have not been able to fulfill the requirements of God Almighty and His Prophet; are recognized by human to human, raised by human to human, even given awards from human to human; it is the conditions that ultimately human forget about themselves, they do not increase their morals, increase their devotion, instead they become amazed at themselves, then they are arrogant as if they were the arm of God. Even though they are only good in reading, good in writing; they don't know what is read and what is written; and have dared to punish other infidels, heretical and misleading [18]. Allah said QS Al-Baqarah (2) 44:

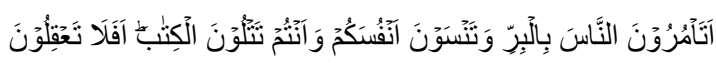

Meaning: "Why do you tell to the people to do good, you forget yourself, while you are reading the holy book of God, are you not understanding?".

\section{Conclusion}

Ruhiology Quotient (RQ) is the intrinsic intelligence that substances possessed by a human that can detect infidelity and believing nature that affects the level of consciousness received by someone who can be known by a human through favors or feelings that radiate to the same conscience blown by the soul to the human body which is the beginning of giving the potential of Ruhiology Quotient (RQ) to human.

To present Ruhiology Quotient (RQ) to someone who can detect the occurrence of disbelief or misuse of science and technology in the Industrial Revolution Era 4.0 that can lead to a multidimensional crisis that is marked by the destruction of human morality, then before the potential for excessive uses of technology deviations from all segments of life occurs. Socially through the abuse of technology, such as pornography, drugs, online gambling, student brawls, body shaming, corruption, hoaxes, phasing, gadget addicts, plagiarism, online games, this indicates the moral crisis has spread in the community and this can be a threat to the generation. It can be known through pleasure or taste through a radiated conscience, before it happens, it can be prevented by performing solemn praying that can prevent cruel and evil acts. So that the 
achievement of the level of faith and sincerity and noble morals of a person can increase and can fortify cybercrime from negative impacts.

\section{References}

[1] B. Mudhary, Mencermati Hakikat Diri: Sebuah Kajian Metafisiska. Surabaya: Pustaka Progresif, 1994.

[2] M. Raharto, Masa Depan Islam Dan Perkembangan IPTEK. Jakarta: Yayasan Festival Istiqlal, 1996.

[3] H. Suwardana, "Revolusi Industri 4.0 Berbasis Revolusi Mental," J. Ilm. Tek. Dan Manaj. Ind., vol. 1, no. 2, pp. 102-110, 2018, doi: http://dx.doi.org/10.30737/jatiunik.v1i2.117.

[4] S. Priatmoko, "Memperkuat Eksistensi Pendidikan Islam 4.0," J. Strudi Pendidik. Islam, vol. 1, no. $2,2018$.

[5] Iswan and Herwina, "Penguatan Pendidikan Karakter Perspektif Islam Dalam Era Milenial IR. 4.0," in Seminar Nasional Pendidikan Revolusi "Membangun Sinergitas dalam Penguatan Pendidikan Karakter pada Era IR. 4.0,” 2018, pp. 21-42, [Online]. Available: https://jurnal.umj.ac.id/index.php/SNP/article/view/2756/2261.

[6] Kuntowijoyo, Paradigma Islam:Interpretasi Untuk Aksi. Bandung: Mizan, 1999.

[7] Iskandar, R. Mohd. Majzub, and Z. Mahmud, "Kecerdasan Emosi dan Komitmen Pekerjaan dalam Kalangan Pensyarah Universiti di Indonesia," J. Pendidik. Malaysia, vol. 34, no. 1, pp. 173-186, 2009. [8] B. UMY, "Inner Capacity Memiliki Peran Spesifik dalam Pengembangan Diri Manusia," 2017. www.umy.ac.id/inner-capacity-memiliki-peran-spesifik-dalam-pengembangan-diri-manusia.html.

[9] S. A. Latif, Super Spritual Quotient “Sosiologi Berpikir Qur'ani dan Revolusi Mental.” Jakarta: PT Elex Media Komputindo, 2017.

[10] A. Mustofa, Menyelam ke Samudra Jiwa dan Ruh. Surabaya: PADMA Press, 2005.

[11] Z. Hakamah, "Ruh dalam perspektif al-qur'an dan sains moderen," UNIVERSUM, vol. 9, no. 2, pp. 243-253, 2008, [Online]. Available: http://download.portalgaruda.org/article.php?article=436821\&val=8451\&title=Ruh.

[12] A. J. Nurihsan, "Pengembangan Kecerdasan Ruhaniah Sebagai Tujuan Pendidikan.” .

[13] T. Tasmara, Kecerdasan Ruhaniah (Transcendental Intelligence): Membentuk Kepribadian yang Bertanggung Jawab, Profesional, dan Berakhlak, A. Jakarta: Gema Insani, 2001.

[14] E. Baharuddin and Z. Ismail, "Kecerdasan Ruhaniah Membentuk Manusia Unggul Spiritual Intelligence Forming Wholesome Being," Islamiyyat, vol. 37, no. 2, pp. 97-105, 2015, doi: http://doi.org/10.17576/islamiyyat-2015-3702-01.

[15] D. Z. Abidin, Tip-Tip Cemerlang Daripada Quran Edisi 2017. Kuala Lumpur: PTS Millenia Sdn. Bhd, 2017.

[16] I. Suproyogo, Pentingnya Membangun Konsep Kecerdasan Ruh dalam Pendidikan. 2018.

[17] T. Firmansyah, "Profesor Imam Suprayogo: Shalat Khusyuk Dapat Satukan Umat Islam," 2018. https://www.republika.co.id/berita/dunia-islam/islam-nusantara/17/11/06/oyyhrw377-profesor- imamshalat-khusyuk-dapat-satukan-umat-islam.

[18] Y. Rose, "Mengenal Subtansi Diri, Shalat, Nabi Muhammad dan Tuhan," 2016. http://archive.rimanews.com/budaya/agama/read/20160720/293369/Mengenal-Substansi-Diri-ShalatNabi-Muhammad-dan-Tuhan . 